\title{
An Evaluation of Monetary Policy and Economic Growth in Nigeria $(2000$ - 2017)
}

\author{
Dr. Cross Ogohi Daniel \& Dr Victor Inim E
}

\author{
Department Of Public Administration/Banking and Finance \\ Nile University Of Nigeria, Abuja \\ Department of Accounting \\ Nile university of Nigeria, Abuja, Nigeria,
}

\begin{abstract}
ABTRACT
The study set to investigate the relationship between monetary policy and economic growth in Nigeria. The scope of the study covers the span of 18 years from 2000-2017. The study uses the GDP as proxy for economic growth and serves as the dependent variable. Other variables such as the interest rate, open market operations, exchange rate, and monetary policy rate and cash reserve ratio were used as the explanatory variables respectively. The study used the time series data of the variables in question and adopted the ordinary least square technique; it also conducted the ADF unit root test for stationary as well as the error correction mechanism for co-integration tests. The study showed that, there is a long run relationship between monetary policy and economic growth. The study found out that, interest rate, open market operations, and exchange rate have positive impact on the GDP, on the other hand monetary policy rate and cash reserve ratio have inverse relationship with the GDP. Hence the study recommends government appropriate policy action on the relevant variables as it concerns the set goals and objectives.
\end{abstract}

Keywords: Monetary, Evaluation, Economy, Growth.

\subsection{BACKGROUND}

Government of various nations adopts some techniques of economic management so as to bring about sustainable economic growth and development and to solve its major macro-economic objectives. One of such techniques is the monetary policy instruments and articulation of how money affects economic aggregates, which is the central element of this research study. The role of monetary policy is very critical in the economic performance of any nation. It provides the impetus for the effective and efficient combination of other policies like fiscal policy to ensure sustainable growth and stabilization of the economy. Onyewu [1] observed that the view of monetary policy dates back to the time of Adam Smith and later championed by the monetary economists, and that the role of monetary policy in influencing macroeconomic objective of economic growth and development includes employment generation, stability in prices, growth in Gross Domestic Product (GDP), Balance of payments equilibrium among others.

In Nigeria, monetary policy has been used since the establishment of the central bank Act of 1958. This role, saddled with the responsibility of formulating and implementing monetary policy by the CBN has facilitated the emergence of active money market where treasury bills, a financial instrument designed for open market operations have grown in volume and value becoming a substantial income earning asset for investors and source of balancing liquidity in the financial market as a backbone of the economy at large.

Two major periods have characterized monetary policy in Nigeria, the pre and post 1986 periods. Before 1986, direct monetary control was used in achieving price stability in Nigeria. The emphasis shifted to market mechanisms after the 1986 Structural Adjustment Programme (SAP) that brought about market liberalization of the economy [2]. Prior to 1986, direct monetary instruments such as selective interest and exchange rates, credit ceilings, cash reserve requirements and special deposits to combat inflation and maintain price stability were employed. The fixing of interest rates at relatively low levels was done mainly to promote investment hence economic growth. Occasionally, special deposits were imposed to reduce the amount of excess reserves and credit creating capacity of banks to combat inflationary pressures [2].

The pre 1986 rigid monetary control framework seems to have failed to achieve the set targets as their implementation became less effective over time, also the non-harmonization of fiscal and monetary policies may have contributed immensely to the 
adverse effect on the growth of the money and capital markets that serve as critical tools for savings mobilization as a stimulus to economic growth. However, the introduction of SAP witnessed a shift to market oriented reform for effective mobilization of savings and efficient resource allocation for investment through the open market operation (OMO) as the main instrument of the market based framework.

In Nigeria recent practices have shown that monetary policy has been based on medium term perspective framework. This shift or tendency however is to free monetary policy implementation from the problem of time inconsistency and again minimize under and over-reaction due to temporary shocks. Policies have ranged from targeting monetary aggregate to monitoring and manipulating policy rates to steer the interbank rate and by extension other market rates in the desired direction [3].

\subsection{Statement of the Problem}

Several works conducted on the subject matter of monetary policy and economic growth in the advanced or developed countries showed that there is substantial evidence of the effectiveness of monetary policy innovations on real economic parameters. However, various monetary policy regimes have been formulated and implemented in Nigeria by the CBN for either expansionary or contra dictionary measures (i.e. to increase or decrease money supply) depending on the set objective it intends to achieve. Nevertheless, previous studies observed in their various studies that, in-spite of the Monetary policy initiatives, to achieve the desired macroeconomic objective, the results have not been absolutely positive and have not been sustainable enough as there is evidence of relatively high rate of unemployment, poverty rate is on the increase, low standard of living as well as rising inflation rate.

The prevailing situation of these macroeconomic vices is an indication that monetary policy implementation have not addressed the problem of economic growth in Nigeria as desired. The question still remains that, does the low rate or pace of economic growth in Nigeria be attributed to inappropriate monetary policy formulation and implementation or actually caused by factors other than monetary policy inefficiencies? It is against this background that the researcher intents to embark on this study on the evaluation of monetary policy and the economic growth of Nigeria.

\subsection{Objective of the Study}

The main objective for this study is to evaluate the contribution of monetary policy on economic growth of Nigeria. Specifically the study will:

i. Determine the impact of monetary policy on economic growth in Nigeria.

\subsection{Research Hypothesis}

This research shall test the hypotheses that,

$\mathrm{H}_{0}$ : Monetary policy has no significant impact on economic growth in Nigeria.

\subsection{LITERATURE REVIEW}

Monetary policy is one of the tools of controlling money supply in an economy of a nation by the monetary authorities in order to achieve the desired level of economic growth. According to Dwivedi [4], monetary policy is essentially a programme of action undertaken by the monetary authorities, generally the central bank, to control and regulate the supply of money in circulation and the flow of credit with a view to achieving predetermined macroeconomic goals. Monetary policy is known to be a vital instrument that a country can deploy for the maintenance of domestic price and exchange rate stability as a critical condition for the achievement of a sustainable economic growth and external viability [5].

\subsection{Economic Growth}

The economic growth is the main objective of any economic policy. In this study, it is proxies as the Gross Domestic Product (GDP) and conceptualized as the monetary value of all goods and services produced in the economy within a specified period of usually one year. According to [6], economic growth is a sustained rise in the output of goods, services and employment opportunities with the sole aim of improving the economic and financial welfare of the citizens. Hardwick et al [7] have defined economic growth as an increase in a country's productive capacity identifiable by a sustained rise in real national income.

\subsection{Empirical Review}

Raffia and Mallik [5] examined the impact of monetary policy on economic growth in Nigeria, using secondary data from central bank of Nigeria statistical bulletin covering the period of 1970 to 2010 . Multiple regressions were employed to analyses data on such variable as money supply, inflation, exchange rate, interest and gross domestic product were all found to have significant effects on the economic growth with the Adjusted $\mathrm{R}^{2}$ of $58 \%$. Following the outcome of this study, it is therefore concluded that exchange rate stability has played a key role in keeping inflation low for most of the transition period, and that the range of 
monetary policy instruments available to the authority has widened in recent years and this has predictable changes in money supply and the price level.

Chukwu (2009) carried out a controlled experiment using a structural vector Auto regression (SVAR) model to trace the effects of monetary policy shown on output and prices in Nigeria. The study assumed that the central bank cannot observe unexpected changes in output and prices within the same period. This places a restriction on the disturbances of the SVAR. Three policy instruments i.e. money supply (MS) minimum Rediscount Rate (MRR) and the real effective Exchange Rate (REER) were used. Overall, the study found evidence that monetary policy innovations carried out on the quantity based nominal anchor of money supply has modest effects on output and prices with a very fast speed of adjustment [8].

Amassoma, Nwosa and Olaiya (2011) have appraised monetary policy development in Nigeria and also have examined the effect of monetary policy on macroeconomic variable in Nigeria for the period 1986 to 2009. The study adopted a simplified ordinary least square technique and also conducted the unit root and co-integration tests. The findings of the study showed that monetary policies have witnessed the implementation of various policy initiatives and has therefore experienced sustained improvement over the years. The result also shows that monetary policy had significant effect on exchange rate and money supply and insignificant influence in maintaining price stability within the Nigerian economy. The study concluded that for monetary policy to achieve macroeconomic objective such as economic growth, there is the need to reduce the excessive expenditure of the government and align fiscal policy along with monetary policy measures [9].

\subsection{METHODOLOGY}

\subsection{Model Specification}

The effect of monetary policy on economic growth is determined by a number of factors which are included on the following econometric model with the functional form of

$\mathrm{GDP}=\mathrm{f}(\mathrm{MPI})$

Where Economic Growth is proxies by the GDP and MPI is the monetary policy indices given as, Interest Rate (INR) Exchange Rate (EXR) Open Market Operations (OMO), Monetary Policy Rate (MPR) and Cash Reserve Ratio (CRR). F represents the functional notation. The functional form of the model therefore becomes, GDP = F (INR, EXR, MPR, OMO, CRR) -------

Stochastically, the regression model is expressed as, GDP $=\beta_{0}+\beta_{1} \mathrm{INR}+\beta_{2} \mathrm{EXR}+\beta_{3} \mathrm{MPR}+\beta_{4} \mathrm{OMO}+\beta_{5} \mathrm{CRR}+\varepsilon$

\subsection{A priori Expectation}

It is expected that the implementation of the monetary policy should enhance economic growth and therefore report as thus: INR $(+), \operatorname{EXR}(+), \operatorname{MPR}(-), \operatorname{CRR}(-)$, OMO (+) = GDP (+)

\subsection{Summary Statistics}

The summary statistics also known as the descriptive statistics shows the various measures of central tendency, measure of dispersion, and distribution of the variables under investigation.

Table 1: Summary Statistics

\begin{tabular}{|l|c|c|c|c|c|c|}
\hline \multicolumn{1}{|c|}{ Statistic } & GDP & INR & OMO & MPR & EXR & CRR \\
\hline Mean & 689405.6 & 17.92611 & 9643.889 & 3067335. & 175.9273 & 7.902500 \\
\hline Median & 695590.0 & 17.42500 & 9973.735 & 2139607. & 141.2011 & 8.537500 \\
\hline Maximum & 979312.4 & 24.85000 & 23388.33 & 9456480. & 360.4930 & 10.75000 \\
\hline Minimum & 329178.7 & 15.14000 & 1036.080 & 878457.3 & 102.1052 & 2.200000 \\
\hline Std. Dev. & 209718.3 & 2.141871 & 7312.845 & 2367650. & 82.94506 & 2.616727 \\
\hline Skewness & -0.256625 & 1.966314 & 0.303762 & 1.612923 & 1.469381 & -1.356066 \\
\hline Kurtosis & 1.772260 & 7.238451 & 1.790496 & 4.681361 & 3.665317 & 3.566947 \\
\hline & & & & & & \\
\hline Jarque-Bera & 1.328078 & 25.07252 & 1.373988 & 9.924799 & 6.809226 & 5.757814 \\
\hline Probability & 0.514768 & 0.000004 & 0.503086 & 0.006996 & 0.033220 & 0.056196 \\
\hline & & & & & & 1169 \\
\hline Sum & 12409300 & 322.6700 & 173590.0 & 55212034 & 3166.691 & 142.2450 \\
\hline Sum Sq. Dev. & $7.48 \mathrm{E}+11$ & 77.98943 & $9.09 \mathrm{E}+08$ & $9.53 \mathrm{E}+13$ & 116958.0 & 116.4034 \\
\hline & & & & & & 18 \\
\hline Observations & 18 & 18 & 18 & & & 18 \\
\hline
\end{tabular}


Source: Author's Computation Using E-views 9.0 Software

It was observed from the summary statistics with reference to the Jarque Bera estimates and probability value that INR, MPR and EXR were not normally distributed due to their low probability values of 0.000002 which is lower than the probability value of 0.05. From the central limit theorem (CLT) non normality does not affect mean values and as such since regression parameters are mean values, the non-normality of the variables does not affect regression parameters in the model to be estimated. On the other hand it was observed that the probability values for GDP, OMO and CRR were normally distributed due to their high probability value of $0.514768,0.503086$ and 0.056196 which was higher than the probability of 0.05 .

\subsection{Stationary Result}

The Augmented Dickey-Fuller test will be used to test for unit root. All the variables were regressed on trend and intercept to determine if they have trend, it was discovered that the four variables have trend and intercept, hence the unit root test involve trend and intercept. The result is presented:

Table 2: Unit Root Stationary Result

\begin{tabular}{|c|c|c|c|}
\hline Variable & ADF Statistics & Critical Value & Stationary Status \\
\hline OMO & -8.382534 & $\begin{array}{l}-4.26274(1 \%) \\
-3.55297(5 \%) \\
-3.20964(10 \%)\end{array}$ & $\mathrm{I}(1)$ \\
\hline CRR & -6.009893 & $\begin{array}{l}-4.26274(1 \%) \\
-3.55297(5 \%) \\
-3.20964(10 \%)\end{array}$ & $\mathrm{I}(1)$ \\
\hline MPR & -4.611492 & $\begin{array}{l}-4.26274(1 \%) \\
-3.55297(5 \%) \\
-3.20964(10 \%)\end{array}$ & $\mathrm{I}(0)$ \\
\hline INTR & -3.860210 & $\begin{array}{l}-3.5743(1 \%) \\
-2.6920(5 \%) \\
-1.2856(10 \%)\end{array}$ & $\mathrm{I}(1)$ \\
\hline GDP & -4.632121 & $\begin{array}{c}-4.26274(1 \%) \\
-3.55297(5 \%) \\
-3.20964(10 \%)\end{array}$ & $\mathrm{I}(1)$ \\
\hline EXR & -3.834543 & $\begin{array}{l}-3.5743(1 \%) \\
-2.6920(5 \%) \\
-1.2856(10 \%)\end{array}$ & $\mathrm{I}(1)$ \\
\hline
\end{tabular}

The critical values for rejection of hypothesis of unit root were from MacKinnon (1991) as reported in e-views 9.0.

Source: Author's Computation

The six variables (OMO, INTR, MPR, CRR, EXR and GDP) underwent unit root test using the Augmented Dickey-Fuller (ADF) test. As is the case most times, all three variables were found to be non-stationary at levels except MPR which was stationary at levels. The remaining five variables (OMO, INTR, CRR, GDP and EXR) were found to be stationary after first difference.

\subsection{Co-Integration and Error Correction Mechanism}

Table 3: ARDL Bound test of Co-integration

\section{Null Hypothesis: No long-run relationships exist}

$\begin{array}{lcc}\text { Test Statistic } & \text { Value } & \mathrm{k} \\ \text { F-statistic } & 31.63964 & 3 \\ & & \\ \text { Critical Value Bounds } & & \\ & & \\ \text { Significance } & \text { I0 Bound } & \\ & & 3.35 \\ 10 \% & 2.26 & 3.79 \\ 5 \% & 2.62 & 4.18 \\ 2.5 \% & 2.96 & 4.68 \\ 1 \% & 3.41 & \end{array}$

Source: Author's Computation 
Due to the non-stationary of time series, the co-integration test was done using the ARDL Bound test. This became necessary to avoid a spurious regression result. Using the ARDL Bound test with critical value from Narayan [10], the variables were cointegrated at 1per cent level of significance since the Wald F- statistics 31.63964 is greater than the critical lower and upper bound (see table 4).

Table 4: Error Correction Mechanism

\begin{tabular}{|c|c|c|c|c|}
\hline \multicolumn{5}{|c|}{ Dependent Variable: GDP } \\
\hline \multicolumn{5}{|c|}{ Selected Model: ARDL(1, 0, 0, 1, 0,0) } \\
\hline \multicolumn{5}{|c|}{ Date: 03/23/19 Time: 07:20 } \\
\hline \multicolumn{5}{|l|}{ Sample: 20002017} \\
\hline \multicolumn{5}{|c|}{ Included observations: 17} \\
\hline \multicolumn{5}{|c|}{ Cointegrating Form } \\
\hline Variable & Coefficient & Std. Error & t-Statistic & Prob. \\
\hline $\mathrm{D}(\mathrm{EXR})$ & -816.3781 & 187.312213 & -4.358372 & 0.0018 \\
\hline $\mathrm{D}(\mathrm{CRR})$ & -976.6233 & 4081.4426 & -0.239284 & 0.8162 \\
\hline $\mathrm{D}(\mathrm{OMO})$ & -6.760279 & 3.974290 & -1.701003 & 0.1232 \\
\hline D(INR) & 4980.0652 & 4670.613 & 1.066255 & 0.3141 \\
\hline $\mathrm{D}(\mathrm{MPR})$ & -0.001395 & 0.003473 & -0.401689 & 0.6973 \\
\hline CointEq(-1) & -0.048672 & 0.012779 & -0.001700 & 4.7845 \\
\hline
\end{tabular}

Source: Author's Computation

Since the variables were found to be co-integrated implying that they have long run equilibrium relationship, it is necessary to test for short run relationship. From table 4.4, the ECM parameter is negative (-) and significant which is -0.048672 , this shows that 4 percent disequilibrium in the previous period is being corrected to restore equilibrium in the current period.

It has been established the variables are co-integrated and also have short run relationship established from the ECM. Hence, the OLS technique will be used to derive the long run impact of the independent variables (OMO, INTR, CRR, EXR, MPR) on the dependent variables (GDP).

4.0 RESULT ANALYSIS AND INTERPRETATION

Table 5: General Regression Result

Dependent Variable: $\log (\mathrm{GDP})$

\begin{tabular}{|c|c|c|c|c|}
\hline Independent Variables & Coefficient & Standard Error & t-Statistic & $P$ value \\
\hline $\mathbf{C}$ & 10.25017 & 0.965075 & 10.62111 & 0.0000 \\
\hline LOG(INR) & 0.236105 & 0.094566 & 3.101535 & 0.0384 \\
\hline LOG(OMO) & 0.336291 & 0.040801 & 8.242251 & 0.0000 \\
\hline LOG(MPR) & 0.027529 & 0.047305 & 0.581946 & 0.5714 \\
\hline LOG(EXR) & -0.114954 & 0.098959 & -3.050062 & 0.0409 \\
\hline LOG(CRR) & 0.026726 & 0.073395 & 0.364134 & 0.7221 \\
\hline R-squared & 0.954386 & F-statistic & 50.21519 & 0.0000 \\
\hline Adjusted R-squared & 0.935380 & Durbin-Watson stat & 1.042589 & \\
\hline
\end{tabular}

Source: Author's Computation 
From the result in table 4.5 the following interpretation can be inferred;

The result obtained, a unit increase in INR on the average holding other independent variables constant will lead to 0.236105 unit increase in GDP. This shows that interest rate has a positive impact on GDP and the relationship is statistically significant due to the probability value of $t$ statistics of 0.0384 which is lower than 0.05 (5\% level of significance).

Also, a unit increase in open market operation (OMO) on the average holding other independent variables constant will lead to 0.336291 unit increases in GDP. This shows that M2 has a positive impact on GDP. This result conforms to apriori expectation. The relationship is statistically significant due to the probability value of $\mathrm{t}$ statistics of 0.0000 which is lower than 0.05 (5\% level of significance).

A unit increase in Money Policy Rate (MPR) on the average holding other independent variables constant will lead to 0.027529 unit increase in GDP. This shows that MPR has a negative impact on GDP. This result conforms to apriori expectation. The relationship is statistically insignificant due to the probability value of $t$ statistics of 0.5714 which is higher than 0.05 ( $5 \%$ level of significance).

Also, a unit increase in exchange rate on the average holding other independent variables constant will lead to 0.114954 unit decrease in GDP. This shows that exchange rate has a positive impact on GDP. This result conforms to apriori expectation. The relationship is statistically significant due to the probability value of t statistics of 0.0409 which is lower than 0.05 ( $5 \%$ level of significance)

A unit increase in Cash Reserve Ratio (CRR) on the average holding other independent variables constant will lead to 0.026726 unit increase in GDP. This shows that CRR has a negative impact on GDP. This result conforms to apriori expectation. The relationship is statistically insignificant due to the probability value of $t$ statistics of 0.7221 which is higher than 0.05 ( $5 \%$ level of significance).

\subsection{CONCLUSION AND RECOMMENDATIONS}

\subsection{Conclusion}

The study investigated the effect of monetary policy on economic growth and monetary policy is found to have long-run relationship with the economic growth and can be used to control the Nigerian economy and essentially a veritable tool for price stability and increased output.

The study used the Augmented Dickey Fuller (ADF) test for unit root test of the regression model for testing the hypothesis. Other statistical tools used are the OLS technique and ARDL Bound test for co-integration of the variables. The study concluded that the interest rate, monetary policy rate and the cash reserve ratio are found to have positive impact on the GDP while the money supply and exchange rate impacts the GDP negatively.

\subsection{Recommendations}

In light of the preceding analysis and findings, the research recommends that

- Money supply and cash reserve ratio should be used as a vital tools for stability of the Nigerian economy when need arises.

- External Rate and interest rate should be used as critical tools for pursuance of major macroeconomic objectives of increased output and employment generation because; the use of these tools encourages domestic investment.

- Monetary Policy rate and implementation should be regular and in line with set goals and made to compliment fiscal policy in Nigeria for enhanced economic growth.

\section{REFERENCES}

[1] Onyewu, Charles (2012) monetary policy and economic growth of Nigeria Journal of Economics and Sustainable Development, 3 (7) pages $62-70$

[2] Uchendu, O.A. "Monetary policy in Nigeria" CBN Economic and financial Review Vol. 33 (2) (2009) 11 - 18.

[3] Okoro, E (2005 the study of monetary policy and macroeconomic stability in Nigeria (1980) extracted from the internet www.2resbank.co Nigeria Ltd

[4] Dwivedi, D.N (2005) Managerial Economics: $6^{\text {th }}$ Edition, Vikas Publishing C \& d - New Delhi

[5] Raffia and Mallik, S.K. (2008) The effect of monetary policy on output: A sign restriction approach. Journal of Macroeconomic Vo. 301756 - 1791.

[6] Osinubi, T.S (2006) monetary policy and macroeconomic stability in Nigeria, a rational expectation approach. Journal of social Research Vol. 12 pages $98-100$.

Hardwick, P., Khan, B. \& Langmead, J., An Introduction to Modern Economics, (4th ed.)

(England: Longman Group Ltd, 1994). 
[7] Hardwick, P., Khan, B. \& Langmead, J., An Introduction to Modern Economics, (4th ed.) (England: Longman Group Ltd, 1994).

[8] Chukwu A. Chuku (2009) Measuring the effects of monetary policy innovation's in Nigeria: A structural vector Autoregressive (SVAR) approach. African journal of accounting economics, finance and banking research Vol. 52009

[9] Amassoma D. Nwosa P.I. and Olaiga, S.A (2011) An appraisal of monetary policy and its effect on macroeconomic stabilization in Nigeria Journal of emerging trends in economics and management sciences volume 2(3) 232-237

[10] Narayan, P. K. (2005). The saving and investment nexus for China: evidence from co-integration tests. Applied Economics 37, pp. 1979-1990 